AVRASYA Uluslararası Araştırmalar Dergisi Cilt:5 •Sayı:12•Özel Sayı 2017•Türkiye

\title{
KIPCHAKS IN THE BATTLES AGAINST THE TATARS
}

Prof. Dr. Paolo OGNIBENE*

\begin{abstract}
In the XIII century the Kipchks seems to have been twice the determing factor in the defeat of the coalitions they took part: The first time in the battle at the Darial pass (Alans and Kipchaks / Mongols) and the second one in the battle at the Kalka river (Russians and Kipchaks / Mongols). The sources in both cases are external. Tha aim of this article is to examine whether the Kipchaks are really responsible for these defeats against the Mongols or if they are just a scapegoat to hide the Russian internal rivalries that led to a heavy defeat.
\end{abstract}

Keywords: Kipchaks/Polovcy/Cumans, Darial, Kalka, Mongols

\section{КИПЧАКИ В СРАЖЕНИЯХ ПРОТИВ ТАТАР}

\section{PEЗЮME}

Известно, что в XIII веке кипчаки дважды являются определяющим фрактором в поражении коалиции, в которую они входят: в первом случае во время сражения алан и кипчаков против татар в Дарьяльском ущелье, во второй раз при битве на реке Калке, где с татарами сражается русско-кипчакская коалиция. Источники в обоих случаях внешние. В статье рассматриваются данные события с целью выявления виноваты ли на самом деле кипчаки в поражениях против татар или, они являются, особенно в русских летописях, козлом отпущения в разгроме, обусловленном внутренним разобщением русских.

Ключевые слова: кипчаки/половцы/куманы, Дарьял, Калка, татары.

Летописи XIII века донесли до нас некоторые бесславные страницы кипчакской истории, а именно два эпизода, связанные с татарским походом под предводительством Джэбэ и Субэдэя, преследующих хорезмского шаха Мухаммеда ${ }^{1}$. В обоих случаях мы имеем дело с внешними источниками, и, следовательно, нужна немалая осторожность для понимания действительной роли, которую сыграли кипчаки: необходимо иметь ввиду, как исторический контекст, так и отношения между кипчаками и народами, летописцы которых описали события. Эти соображения могут отчасти смягчить негативную оценку, хотя и не изменят тяжесть ситуации.

Первый из двух эпизодов относится к сражению между татарским войском и аланско-кипчакской коалицией в Дарьяльском ущелье (арабские источники), второй - битва русских и кипчаков против татар на реке Калке (русские источники). Если отношения между русскими и кипчаками всегда были достаточно напряженными, и в русских летописях негативное мнение о кипчаках встречается постоянно ${ }^{2}$, то то же самое нельзя сказать об арабах, у которых не было особых причин для предвзятости против кипчаков.

\footnotetext{
"Università di Bologna, Department of Preservation of the Cultural Heritage, paolo.ognibene4@unibo.it

1'Alā al-Dīn Muhammad, Khwāārazm-Shāh. Els 1993: 39.

2 «Якоже се и при насъ нынь Половчи законъ держать отець своихъ, кровь проливати, а хвалящеся о сихъ, ядуще мерьтвечину и всю нечистоту, хомБки и сусолы; поимають мачехи своя, ятрови, и ины обычая отець своихъ творять»: ПСРЛ 1846: 7; таким же образом татары описаны в западных хрониках: «sunt enim corpore terribiles, voltu furiosi, oculis iracondi, manibus rapaces, dentibus sanguinolenti et eorum fauces ad carnem hominum
} 
В 1218 году, после инцидента в Отраре, Чингисхан идет войной на Хорезм (JUVAINI 1991: 98-102). Мухаммед разделяет свое войско с целью защиты различных восточных областей своего царства, но такая тактика оказывается ошибочной, и татары его побеждают. После бегства Мухаммеда на запад Чингисхан из Самарканда приказывает Джэбэ, Субэдэю и Тугачару преследовать шаха и дает в их распоряжение тридцатитысячное войско ${ }^{3}$. Достигнув берегов Каспийского моря и узнав, что Мухаммед уже умер, ${ }^{4}$ они получают разрешение продвигаться на север и возвратиться в Центральную Азию обогнув Каспий ${ }^{5}$. Таким образом они сталкиваются вначале с армянами и грузинами и далее доходят до Ширвана ${ }^{6}$. В Ширване местное население дает татарам гида, который их приводит к Дарьяльскому ущелью, где им преграждает путь аланскокипчакская коалиция. Дарьял - хорошо защищаемое место и татары не в состоянии преодолеть его. Тогда вступает в ход татарская дипломатия: налаживается контакт с кипчаками, которые по словам арабского летописца, пренебрегают коалицией и покидают аланов на произвол судьбы. По летописи распаду коалиции способствовали с одной стороны слова татар, подчеркивающие единую этническую принадлежность с кипчаками, с другой стороны богатые дары, полученные от татар:

«(Татары) отправили посла к Ширваншаху, владетелю ширванского ущелья, сказать эму, чтобы он прислал к ним посла, для улажения мира между ними. Он отправил десять человек из знатнейших людей своих. Они скватили

comedendam et humanum sanguinem absorbendum omni tempore sunt parate»: MGH 1888: 207; приход татар связывается русским летописцем с божьим желанием наказать кипчаков: «и тако измроша убиваеми гнђвом божиемь и пречистыя его матере, много бо зла створиша ти оканьнии Половчи Русьскои земли, того ради всемилостивыи богъ хотя погубити безбожныя сыны Измаиловы Куманы, яко да отмьстять кръвь крестьяньску, еже и бысть над ними безаконьными»: НПС 1950: 61.

${ }^{3}$ «Tchinguiz-Khan à l'époque où il avait appris que Sultan-Mohammed avait quitté Termed et frachi l'Amou avec une suite peu nombreuse, était resté lui-même pour faire le siége de Balkh et avait envoyé à la poursuite du sultan Tchèpe-Noyân, Souboudaï-Bèhadour et Toughatchar, le Qounqrât, chacun avec dix mille hommes»: ABOUL-GHAZI, H.Mon, 125 (чаг. текст, 66). B армянских летописях указывается, что войско состояло из 20 тысяч человек: «С наступлением 669 года какие-то неведомие полчища, говорящие на неизвестном языке, называемые Мугал и Татар, выступили из стран Чин и Мачин, и в числе 20 тысяч человек, проникли до равнин Гурарских со стороны Агвании": ПАТКАНОВ, 1874, 2.

${ }^{4}$ Мухаммед умирает на маленьком острове Каспийского моря: «Cette ile n'est désignée par les historiens que sons le nom d'Absukoun, ou d'ile de la mer d'Absukolun c'est-à-dire de la mer Caspienne. Absukoun était un bourg maritime qui servait de port à la ville de Djiourdjan dans le Mazénderan»: OHSSON 1834: 255, nt. 1; также в: AвOU'L FEDĀ, An.: 95; может быть полуостров Гумиш-Тепе: HOWORTH 1876: 82.

${ }_{5}$ «В год под циклическими знаками 1223 Субутай представил Чингису доклад, в котором просил (послать его) против кипчаков. Он обогнул с войсками Каспийское море; двигаясь далее, он дошел до хребта Тай-хе»: ИвАнОВ 1914, 19.

${ }_{6}$ «Владельцы Дербента не пропустили их. Тогда монголы перешли через Кавказские горы по трудным местам, забрасывая обрывы деревьями, камнями, их имуществом, и даже лошадьми и военными машинами»: ПАТКАНОВ 1874: 4; "lls prirent è Chémâkhi dix guides et en tuèrent un pour effrayer les neuf autres qu'ils menacèrent du même sort s'ils ne les guidient pas bien, puis ils continuèrent leur marche, en passant par Derbent»: ABOUL-GHAZI H.Mon.: 129 (чаг., 121); «Ширваншах прислал десять человек из вельмож своего народа; одного из них монголы убили, а другим сказали: если вы покажите нам путь через Дербенд, мы вас пощадим, в противном случае мы вас тоже убьем»: РАшид АД-Дин Сб. лет.: 228-229; «Потом пришли они в Дарбанд; никто не помнит, чтобы какое-то войско прошло когданибудь по этому пути, но они воспользовались военной хитростью, благодаря которой смогли пройти» (пер. П.О.): JUVAINI, G.Kh.: 175; ОНЬИБЕНЕ - САЯФ 2011: 77-89. 
одного из них и убили его, а остальным сказали: если вы нам укажете путь, по которому мы можем пройти, то вам будет пощада, если же не делаете этого, то мы убьем вас, как убили этого. Те сказали: через это ущелье нет никакой дороги, но в нем есть место, которое удобнее всех дорог. Они пошли с ними на этот путь, перебрались по нем и оставили его позади себя. Перебравшись через Ширванское ущелье, татары двинулись по этим областям, в которых много народов, в том числе Алланы, Лезгины и турские племена. Они ограбили и перебили много лезгин, которые были отчасти мусульмане и отчасти неверные. Нападая на жителей этой страны, мимо которых проходили, они прибыли к Алланам, народу многочисленному, к которому уже дошло известие о них. Они употребили все свое старание, собрали у себя толпу кипчаков, и сразились с ними. Ни одна из обеих сторон не одержала верха над другою. Тогда татары послали к кипчакам сказать: мы и вы одного рода, а эти Алланы не из ваших, так что вам нечего помогать им; вера ваша не похожа на их веру, и мы обещаем вам, что не нападем на вас, а принесем вам денег и одежд сколько хотите; оставьте нас с ними. Татары принесли им то, что было выговорено, и Кипчаки оставили их. Тогда татары напали на Аллан, произвели между ними избиение, безчинствовали, грабили, забрали пленных и пошли на Кипчаков ... Придя к Судаку, Татары овладели им, а жители его разбрелись ... Татары пробыли некоторое время в земле Кипчацкой, но потом двинулись в страну русских» (ТИЗЕНГАУЗЕН 1884: 25$)^{7}$

Частая смена союзников в некотором смысле обычное явление в логике войны в этом ареале, но за решение покинуть коалицию сами же кипчаки заплатили дорогой ценой. Аланы тоже долгое время колебались на разных фронтах в войнах между сасанидами и византийцами (OGNIBENE 2009: 261-272), в то время как кипчаки многократно принимали участие во внутренней борьбе русских, обличаясь то в союзников, то во врагов. В передаче событий арабским летописцем отсутствует какая-либо моральная оценка действий кипчаков, только простое описание фрактов, которые не складываются благоприятно для кипчаков, хотя и замечается некоторая ирония при изложении данных событий. Если сегодня для нас отступничество кипчаков расценивается как малодостойный поступок, такая оценка полностью отсутствует в арабской летописи, где подчеркивается только ошибка, допущенная кипчаками, не сумевшими распознать действительную опасность со стороны татар, следствием которой явился полный разгром народов Центрального Кавказа. (OGNIBENE 2013а: 154175). После удачного перехода через Дарьяльское ущелье татары преследуют кипчаков, убивают многих и забирают все дары, данные ими ранее:

«Чингиз хан возвратился и занял Газну. Было убито много людей и многих взяли в плен, в то время как часть монголов направилась к кипчакам, где с

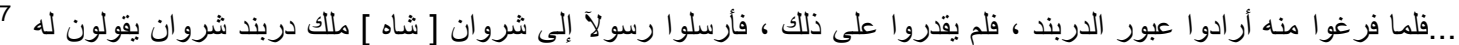

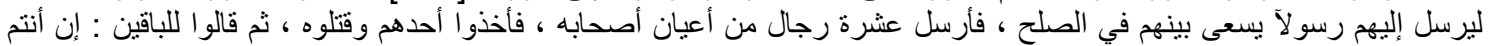

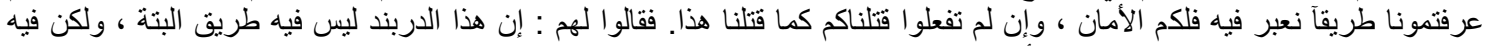

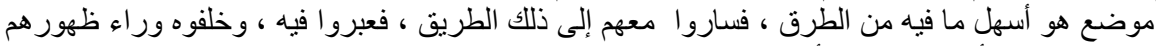

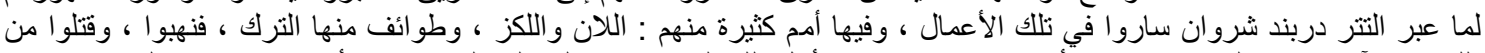

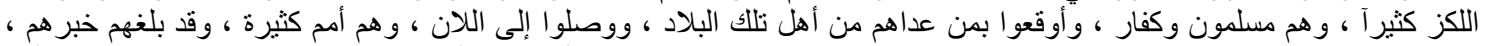

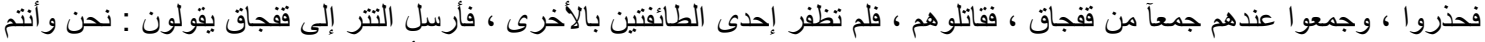

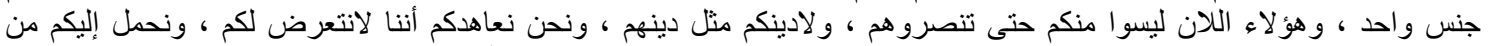

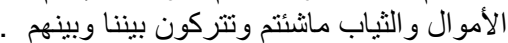

فاستقر الأمر بينهم على مال حملوه وثياب وغير ذلك ، فحملوا إليهم ما استقر وفارقهم ققجاق فأوقع النتر باللن ، فقتلوا منهم وأكثروا

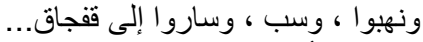

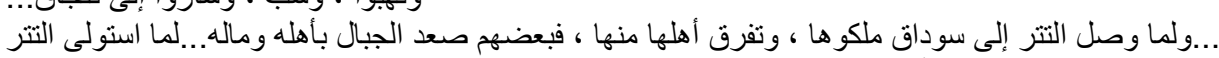

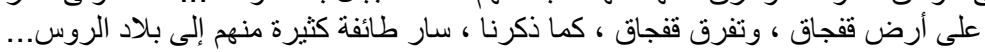


ними произошло столкновение, и кипчаки были побеждены, и монголы захватили большой город кипчаков, который называется Судак, и также само поступили с народом, который называется лезгины, их страна рядом с Дербент Ширваном. После этого монголы направились к руссам и кипчакам. И произошла между ними великая битва. Победили монголы» (ABOU'L FEDĀ, An.) ${ }^{8}$.

Русские впоследствии неоднократно подчеркивают так называемые «листи татарискыя» ${ }^{9}$, но война, где сталкиваются два противоположных мира кочевой и оседлый зачастую воспринимается неоднозначно, каждым из них посвоему. В русско-кипчакских отношениях имеют место частые случаи недобросовестности и обмана, также как и случаи опрометчивости и плохой оценки действительных силовых соотношений ${ }^{10}$.

Кипчакско-татарское столкновение засвидетельствовано различными источниками, которые подтверждают несомненное поражение кипчаков:

«Eodem anno fuerunt tartari in terra valvorum paganorum, qui parthi a quibusdam dicuntur, qui panem non comedunt, sed carnibus crudis pecororum suorum vescuntur. Et pugnaverunt tartari cum eis, et debellaverunt eos, et percusserunt omnes in ore gladii, et alii fugerunt ad ruthenos, petentes auxilium ab eis» (MGH 1874: 316).

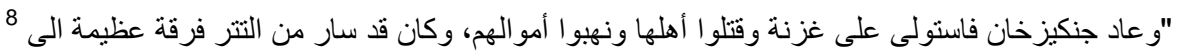

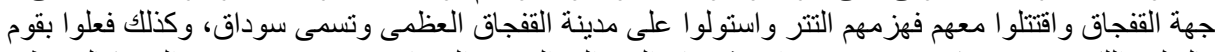

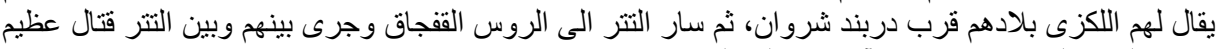

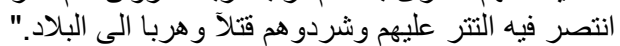

9 Приводимая неоднократно в летописях: «(...) не ведущими же Руси листи татарискыя, исходаахъ противъ ими со кресты, оже избиша вся»: ПСРЛ 1851: 173; «(...) Руси же, не вядяхъ злобы и листи татарьскиа и ненависти на христиани, исходаахъ протиъ ими со кресты, они же избивахъ всехъ»: ПСРЛ 1949: 121. При сравнении одного и того же отрывка в двух летописях заметно, что со временем оценка татар становится все более негативной.

10 В этом отрывке русские предательски убивают некоторых кипчакских князей: ПСРл 1846: 97: «Въ то же льто придоша Половци, Итларь и Кытанъ, къ Володимеру на миръ, приде Итларь въ градъ Переяславль, а Кытанъста межи валома съ вои, и вда Володимеръ Кытанови сына своего Святослава въ тали, а Итларь бысть въ градь съ льпшею друженою (...) и начаша думати дружина Ратибора съ княземъ о погубленьи Итларевы чады (...) И послуша ихъ Володимеръ, и въ ту нощь посла Володимиръ Славяту съ нちколикою дружиною и съ Торкы, межи валы; выкрадше первое Святослава, потомъ убиша Кытана и дружина его избиша. Вечеру сущю тогда суботному, а Итларевы въ ту нощь лежащю у Ратибора на дворь съ дружиною своею и не вьдуче, что ся надъ Кытаном створи, наутрия же въ недьлю, заутрени суще годинь, пристрои Ратиборъ отрокъ въ оружьи, истобку пристави истопити имъ. И присла Володимеръ отрока своего Бандюка по Итлареву чады, и рече Бандюкъ Итлареви зоветь вы князь Володимеръ, рекль тако обувшеся, въ тепль избь заутрокавше у Ратибора, приђдите ко мнь. И рече Итларь: тако буди. Яко влоша въ истобку, тако запрени буша, възльзше на истобку, прокопаша и верхъ, и тако Ольбергъ Ратиборичь приима лукъ свой и наложивъ стрьлу, удари Итларя въ сердце, и дружину его всю избиша; и тако зль испроверже животъ свой Итларь, въ недьлю сыропустную, въ часъ 1 дне, месяца февраля въ 24 день». С другой стороны, ранее данное слово часто не сдерживалось, что было достаточно распространенным явлением. Вспомним убиение князей Дубровских на реке Калке: «(...) а у города того оста воеводь Цьгырканъ и Тешюканъ на Мьстислава и на зяти его на Андрья и на Ольксандра Дубровьцьскаго беста бо 2 князя съ Мьстиславом. Ту же и бродници съ Татары быша, и воевода Плоскына, и тъ оканьныи воевода цьловавъ кресть честьныи къ Мьстиславу и къ объм князема, око ихъ не избити, нъ пустити ихъ на искупъ, и сълга оканьныи прђда ихъ извязавъ Татаромъ а городъ възяшь и люди иськоша и ту костью падоша а князи имъше издавиша подъкладъше подъ дъскы а сами вьрху сьдоша обьдати, и тако животъ ихъ концяша»: НПС 1950: 63. 
«Татары пошли на Кипчаков, которые спокойно разошлись на основании мира, заключеннаго между ними, и узнали о них только тогда, когда те нагрянули на них и вторгнулись в землю их. Тут стали они нападать на них раз за разом, и отобрали у них вдвое против того, что им принесли. Услышав эту весть, жившие вдали Кипчаки бежали без всякого боя и удалились; одни укрылись в болотах, другие в горах, а иные ушли в страну Русских» (ТИЗЕНГАУЗЕН 1884: 25-26).

Русские летописи повествуют об этих событиях наиболее подробно:

«Слышахомъ бо, яко многы страны попльниша, Ясы, Обезы, Касогы, и Половьчь безбожьныхъ множество избиша (...) И прибегоша оканьнии Половчи, избьныхъ избытъкъ, Котянь с ыньми князи, а Данилъ Ковяковичь и Гюрги убьена быста, с нимь множьство Половьчь» (НПС 1950: 62) ${ }^{11}$.

После поражения часть кипчаков направляется к русским за помощью. Отношения между русскими и кипчаками всегда были достаточно сложными, но во избежание постоянного состояния войны достигаются договоренности, прибегая при этом и к заключению совместных браков. Некоторые русские князья взяли в жены кипчакских княгинь, и наоборот, кипчакские князья женились на русских княгинях. Поэтому нет ничего странного в том, что кипчаки обращаются за помощью к русским в борьбе с новым врагом, появившемся на горизонте из ниоткуда ${ }^{12}$ :

«И приде съ поклономь съ князи Половьчьскыми къ зяти въ Галичь къ ॥ Мьстиславу и къ всемъ княземъ русьскымъ, и дары принесе многи: кони и вельблуды и буволы и дЂвкы, и одариша князь русьскыхъ, а рекуче тако: нашю землю днесь отъяли, а ваша заутро възята будеть, и възмолися Котянь зяти своему» ${ }^{13}$ (НПС 1950: 62).

Мстислав
русских князей

«Мьстислав же поця молитися княземъ русьскымъ, братьи своеи, рекя тако оже мы, братье, симъ не поможемъ, тъ си придатися к нимъ, тъ оньмъ больши будети сила»: (НПС 1950: 62).

Несмотря на то, что летописцами подчеркивается то, что русские вступают в войну с татарами по просьбе кипчаков, логика убеждений Мстислава ясна. С другой стороны русские привыкшие к столетней войне с кипчаками, недооценили новых врагов: в их глазах это просто кочевой народ, который смирить не составит большого труда, как смирили другие до них народы при помощи меча или прибегая к дипломатии.

\footnotetext{
${ }^{11}$ Далее рассказ дает крайне негативную оценку кипчаков, называя их «безбожные сыны Измайловы». По мнению русских кипчаки: «Исьшили бо суть си отъ пустыня Нитривьскыя, межю встокомъ и сьверомъ; исшли бо суть ихъ кольнъ 4: Торкъмени и Печеньзи, Торци, Половци (...) А Измаиль роди 12 сына, отъ нихъ же суть Торкъмени, и Печеньзиі, и Торцыі, и кумани, рекше Половци, иже исходять отъ пустынь». ПСРЛ 1846: 99-100. О татарах также скажут впоследствии: «Въ льто 6731. (...) о нмхъ же Мефодий Патомьскый епископъ свђдБтельствуеть: яко си суть ишли изъ пустыня Ертриевьскы, суще межю встокомъ и сьверомъ»: ПСРЛ 1846: 189.

${ }_{12}$ Русские также ничего не знают о новых прибывших: «Том же льть по грехомъ нашимъ придоша языци незнаеми их же добрь никто же не вьсть кто суть и отколе изидоша и что языкъ ихъ и котораго племене суть и что вьра ихъ»: НПС 1950: 61.

13 «Прибьгшимъ же Половцемь въ Рускую землю глаголющимъ же имъ Рускимъ княземь аще не поможета намъ мы нынь исьчени быхомъ а вы наутрье исьчени будете»: ПСРЛ 1843: 163

${ }^{14}$ Хотя в Ипатиевской летописи нет какого-либо упоминания о Котяне.
} 
Вся Русь вместе с кипчаками движется против татар ${ }^{15}$. Повествование в Новгородской летописи развивается интенсивным темпом, стремительно сменяя события: вначале прибывают татарские послы с предложением не начинать войны и просьбой прогнать кипчаков:

«Тъгда же увьдавъше Татари, оже идуть русстии князи || противу имъ, и прислаша послы, къ русскымъ княземъ: се слышимъ оже идете противу насъ, послушавше Половьчь, а мы вашеи земли не заяхомъ, ни городъ вашихъ, ни селъ вашихъ, ни на васъ придохомъ, нъ придохомъ богомь пушени на холопы и на конюси свое на поганыя Половче. А вы възмите с нами миръ, аже выбежать къ вамъ а биите оттоль, а товары емлите к собе: занеже слышыхомъ, яко и вамъ много зла створиша, того же дђля и мы биемъ» (НПС 1950: 62).

Но русские убивают татарских послов и продолжают идти навстречу врагу $^{16}$. Вторая посольская миссия татар не приводит ни к чему новому:

«Того же русстии князи не послушаша, нъ послы избиша, а сами поидоша противу имъ, и не дошьдъге Ольшья, и сташа на Дньпрь. И прислаша к нимъ второе послы Татари, рекуще тако: а есте послушали Половьчь, а послы наша есте избили, а идете противу нас, тъ вы поидите, а мы васъ не заяли, да всемх богъ» (НПС 1950: 62).

После происходит первое столкновение с передним отрядом татар. Татары применяют максимально простую стратегию: посылают слабые войска вперед, чтобы создать эффект отступления, заставляя противника преследовать их пока не достигнут удобного для сражения места, где и сосредоточены главные силы татар. На этот раз в татарскую ловушку попадают кипчаки: они преследуют татар, а когда упираются в их усиленные войска, обращаются в бегство и, убегая, затаптывают русский лагерь, создавая полнейший хаос:

«И послаша въ сторожихъ Яруна с Подовьци, а сами станомь сташа ту. Тъгда же Ярун съступися с ними, хотя битися, и побегоша не успьвъше ничтоже Половци назадъ, и потъпташа бежаще станы русскыхъ крязь, не успьша бо исполчитися противу имъ, и съмятошаса» (НПС 1950 : 63).

Данный отрывок летописи заслуживает особого внимания: русские отправляют вперед кипчаков во главе с Яруном, Ярун решает вступить в бой с татарами, что и приводит к полной катастрофре. (OGNIBENE 2013: 691-711; OGNIBENE 2003 : 163-165). Свидетельства такой неудержимости кипчаков, которая часто приводила их к поражениям, неоднократны в русских летописях 17.

\footnotetext{
${ }^{15}$ «Et pervenit verbum per universiam Rusciam, ut pugnarent cum tartaris, et exiverunt reges de tota Ruscia contra tartaros et non valuerunt pugnare cum eis, et fugerunt coram eis»: MGS 1874: 316; «и поидоша, съвъкупивше землю всю русскую противу татаром»: НПС 1950: 62. ${ }_{17}^{16}$ Татары делают то же самое в Ширване.

${ }^{17}$ Вот пример недооценки кипчаками реальной опасности: ПСРЛ 1846: 119: «Половци же слышавше, яко идеть Русь, собрашася безъ числа и начаша думати, и рече Урусоба: просимъ мира у Руси, яко крБпко имуть битися съ нами, мы бо много зла створихомъ РусскБй земли. И рьша уньйшии Урусобь: аще ты боишися Руси, но мы ся не боимъ; ся бо избивше, поидемъ въ землю ихъ и приимемъ грады ихъ и кто избавити и отъ насъ (...) поидоша половци и послаша предъ собою въ стороже Алтунопу, иже словяше въ нихъ мужствомъ; такоже Русскић князи послаша стороже своь, и устерегоша Рускиђ стороже Олтунопу, и обиступивъше и, и убиша Алтунопу и сущая съ нимъ; и не избысть ни единъ, но вся избиша. И поидоша полкове аки борове, и не бь презрьти ихъ; и Русь поидоша противу имъ. И Богъ великый вложи ужасть велику въ Половчь, и страхъ нападе на ня и трепетъ отъ лица Русскыхъ вой, и дремаху сами, и конемъ ихъ не бь спьха въ ногахъ; наши же съ весельемъ на коньхъ поидоша къ нимъ. Половци же видевше устремленье
} 
Учитывая данное описание ответственность кипчаков за поражение на реке Калке неоспорима, но русский летописец добавляет также некоторые интересные детали:

«Мьстиславъ же, Кыевскыи князь, видя се зло не движеся съ мђста никаможе, сталь бо бь на горь надъ рькою над Калкомь, бь бо мђсто то камянисто, и ту угоши городъ около себе в кольхъ, и бися с ними из города того по 3 дни» (НПС 1950 : 63).

Мстислав киевский не делает ни шага с укрепленного места, где он находится, чтобы помочь другим князьям: нам неизвестно, происходит ли это по тактическим соображениям или это очередное доказательство соперничества между русскими князьями.

Кипчаки не ограничиваются разгромом русского лагеря: в суматохе и общей панике, которая заставляет бежать Мстислава до самого Днепра, (при этом эмоциональное напряжение повествования такое сильное, что под стать и почти копия геродотскому рассказу о бегстве Дария и его армии со скифских земель $)^{18}$, кипчаки делают все возможное, чтобы спастись, убивая русских и отнимая у них лошадей: «а иныхъ Половци побиша ис коня» (НПС 1950: 63).

Исходя из сказанного можно сделать некоторые заключения относительно поведения кипчаков и их роли в описываемых событиях. В первом случае поведение кипчаков нельзя назвать элегантным, но менять союзников тогда не являлось чем-то необычным и что не так уж редко и в наши дни. Тем не менее решение кипчаков приводит к разгрому аланов и к бедствию самих кипчаков. Во втором случае на кипчаках не лежит ответственности за то, что они вовлекли русских в войну против татар: русские сами понимают, что если не помогут кипчакам, то должны будут воевать с двумя противниками, хотя летописец подчеркивает также роль, которую сыграли дары от кипчаков и их родственные связи с Мстиславом. Если и говорить об ответственности кипчаков, то она ограничивается исключительно недальновидностью и некомпетентностью, проявленными на поле битвы: похоже, что решение атаковать татар было принято самостоятельно кипчаками без предупреждения русских войск, которые в это время спокойно располагались в лагере, и в итоге были уничтожены внезапным отступлением кипчакского войска. Что касается истребления русских во время отступления, то оно не вызывает удивления: в момент всеобщего бегства, каждый думает о том как бы спастись. Кипчаки представляются русскими летописцами идеальными виновниками всякого несчастья и данный эпизод только усилил негативное суждение о них, которое сопровождает все летописи и остается неизменным с течением лет.

\section{БИБЛИОГРАФИЯ}

Руское на ся, не доступивше бо побьгоша предъ Русскими полки; наши же погнаша, ськуша я».

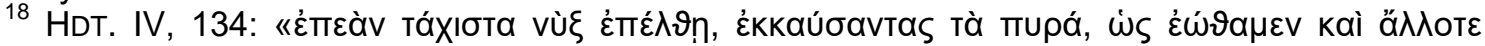

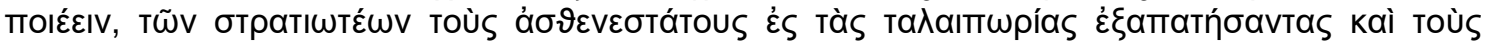

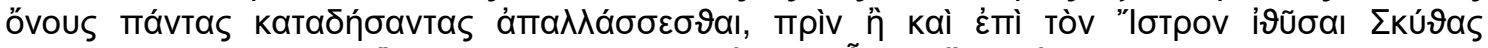

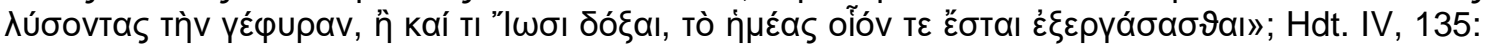

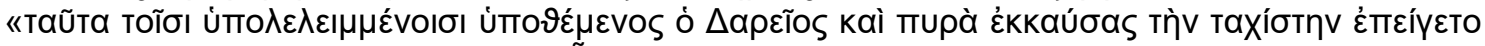

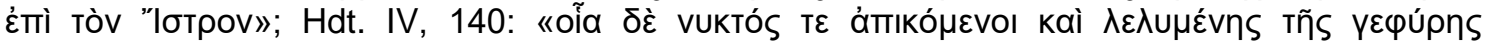

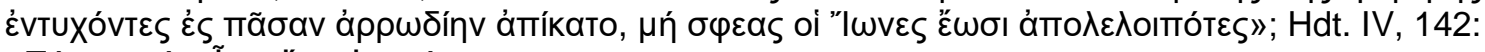

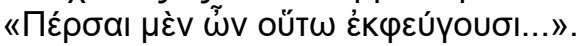


ABOU'L FedĀ, An. (1882), [Abū'l-Fidā, Ismā'īl b. (al-Afợal) 'Alī b. (al-Mužaffar) Maḥmūd b. (al-Manșūr) Muhammad b. Taqī al-Dīn 'Umar b. Š̉āhanšāh b. Ayyūb, al-Malik alMu'ayyad 'Imād al-Dīn]: "Résumé de l'histoire des Croisades tiré des Annales d'Abou'l Fedā". In: Recueil des historiens des croisades, publié par les soins de l'Académie des inscriptions et belles-lettres. Historiens orientaux, t. 1, Paris, 1872, 1186.

ABOUL-GhaZI H.Mon. (1993), [Abu '-Gāzi Bahādur Hān]: Histoire des Mongols et des Tartares, publié traduite et annoté par le Baron Desmaisons, t. 1: texte; t. 2 : Traduction. Sankt Peterburg, 1874.

Els (1993) The Encyclopaedia of Islam. Index. Leiden - New York - Köln.

GRIGOR AKNERC'I Pat. T'at'. (1974), Patmowt'iwn T'at'arac', Ërowsałēm,

HDT. $=$ Herodotus, Ed. C. Hude, Oxford (OCT).

HOWORTH Henry, (1876), History of the Mongols from the IX to the XIX Century, t. 1: The Mongols Propers and the Kalmuks, London.

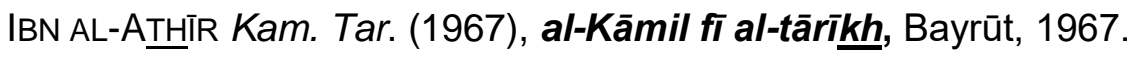

IVANOV A. Ivanovic (1914), "Pochody mongolov na Rossiju po oficial'noj kitajskoj istorii Juan'-ši”. In: Zapiski razrjada voennoj archeologii i archeografii imperatorskogo russkogo voenno-istoričeskogo obščestva, III, Petrograd: 14-22.

ILOVAJSKIJ Dmitrij, (1879), “Kalkskoe poboišče”. Russkaja starina, XXV: 691-706.

JuVAINI G.Kh. (1991), ['Alā' al-Dīn 'Ata-Malik Djuwaynī], Gengis Khan. Traduzione di Gian Roberto Scarcia. Milano, 1991.

MGH (1874), Monumenta Germaniae Historica. Scriptores, t. 23, Hannover (Chronicon Lyvoniae: 231-332).

MGH (1888), Monumenta Germaniae Historica. Scriptores, t. 28, Hannover (Ex Mathei Parisiensis Cronici Maioribus: 74-389).

NPS (1950), Novgorodskaja pervaja letopis' staršego izvoda, Moskva - Leningrad.

OGNIBENE Paolo, (2003), "Jäbä and Sübä'ätäi's Military Expedition to the West". Nartamongæ. The Journal of Alano-Ossetic Studies: Epic, Mythology and Language, II: 163-186.

OGnibene Paolo, (2003), "Gli Alani tra la Persia e Bisanzio". Bizantinistica. Rivista di Studi Bizantini e Slavi. Serie II. Anno XI, Spoleto: 261-272.

OGNIBENE Paolo, (2013), "La battaglia sul fiume Kalka". In: Polidoro. Studi offerti ad Antonio Carile. A cura di Giorgio Vespignani, Spoleto: 691-711.

OGNIBENE Paolo, (2013a), "Il primo scontro alano-mongolo nel Caucaso". Slavia, 3: 154-175.

OGNIBENE P- SAYAF G, (2011), "Pochod Džèbè i Subèdèja na Kavkaz: arabskie istočniki". In: Languages and Cultures in the Caucasus. Papers form the International Conference Current Advances in Caucasian Studies, Macerata, January 21-23 2010, Edited by V. Springfield Tomelleri, M. Topadze, A. Lukianowicz with the Collaboration of $O$. Rumjancev [Studies on Language and Culture in Central and Eastern Europe, Hrsg von C. Voß, Band 16], München - Berlin: 77-89.

OHSSON Constantin, (1834), Histoire des Mongols depuis Tchinguiz-khan jusqu'à Timour bey ou Tamerlan, t. 1, Paris. 
PATKANOV Kerope Petrovič, (1873), Istorija mongolov po armjanskim istočnikam, vypusk pervyj, zaključajuščij v sebe izvlečenija iz trudov Vardana, Stefana Orbeliana i Konteblja Sembata, Sankt-Peterburg.

PATKANOV Kerope Petrovič, (1874), Istorija mongolov po armjanskim istočnikam, vypusk vtoroj, zaključajuščij v sebe izvlečenija iz istorii Kirakosa Gandzakeci, SanktPeterburg.

PSRL (1843), Polnoe sobranie russkich letopisej, II: Ipatievskaja letopis', SanktPeterburg.

PSRL (1846), Polnoe sobranie russkich letopisej, I: Lavrentievskaja i Troickaja letopisi, Sankt-Peterburg.

PSRL (1851), Polnoe sobranie russkich letopisej, V: Pskovskija i Sofiskija letopisi, Sankt-Peterburg.

PSRL (1949), Polnoe sobranie russkich letopisej, XXV: Moskovskij letopisnyj svod konca 15-go veka, Moskva.

RAŠID AD-DIN Sb. let. (1952), Sbornik letopisej, I/2, Moskva - Leningrad, 1952.

REINAUD - MC GUCKIN DE SLANE (1840), Géographie d'Aboulféda: texte arabe publié d'après le manuscrits de Paris et de Leyde aux frais de la Societe Asiatique, Paris.

ROMANOV V. K., (1981), "Idejno-istoričeskoe osmyslenie kalkskoj bitvy v russkom letopisanii”. In: Kulikovskaja bitva v literature i iskusstve, Moskva: 79-104.

ROMANOV V. K., (1983), Bitva pri reke Kalke. Avtoreferat. MGU.

SVERDLOV Michail, (1963), "K voprosu o letopicnych istočnikach povesti o bitve na reke -Kalke". Vestnik LGU, serija istorii jazyka i literatury, 2, vyp. 1: 142-143.

TIZENGAUZEN Vladimir, (1884), Sbornik materialov otnosjaščichsja k istorii Zolotoj Ordy, I, Sankt-Peterburg, 1884. 